\title{
Comparative Study of Roman Iron Slags Discovered in the Roman Auxiliary Fort and Settlement of Călugăreni
}

\author{
Enikő BITAY ${ }^{1}$, Irén KACSÓ ${ }^{2}$, Szilamér Péter PÁNCZÉL ${ }^{3}$, Erzsébet VERESS ${ }^{4}$ \\ ${ }^{1}$ Sapientia Hungarian University of Transylvania, Faculty of Technical and Human Sciences, Târgu-Mureş, \\ Romania,ebitay@ms.sapientia.ro \\ ${ }^{2}$ National Institute for Research and Development of Isotopic and Molecular Technologies (INCDTIM), \\ Cluj-Napoca, Romania, iren.kacso@gmail.com \\ ${ }^{3}$ Mureş County Museum, Târgu-Mureş, Romania, pszilamer@yahoo.com \\ ${ }^{4}$ Transylvanian Museum Society, Cluj-Napoca, Romania, veresserzsebet@gmail.com
}

\begin{abstract}
Iron slag samples unearthed at the eastern border of Roman Dacia, in the auxiliary fort and the military settlement of Călugăreni (Mikháza) are investigated by macroscopic inspection, optical microscopy (OM) and FTIR spectroscopy in order to comparatively characterize their macro- and microstructure as well as their mineralogical composition. During the recent archaeological excavations, a large number of iron artefacts were discovered together with a great quantity of iron slag fragments. The present paper focuses on the data obtained from 17 slag samples.
\end{abstract}

Keywords: iron slags, macroscopic investigation, optical microscopy, FTIR spectroscopy.

\section{Introduction}

Among other resources, the procurement of rich ore and salt mines were a determining factor in the decision of the Romans to conquer Dacia. In the territory of the defeated Dacian kingdom a Roman province was organized at the beginning of the $2^{\text {nd }}$ century, and continued to develop until the middle of the $3^{\text {rd }}$ century. After the conquest the border defense system (limes) of the new province was established, similar to other parts of the Roman Empire. On the borderline - the outer defensive line of the circular defence system - auxiliary units were stationed [1,2], while in the central part and on the more vulnerable western border the auxiliary units and legions were also positioned. Due to the frequency of barbaric incursions and the economic and political instability of the Empire, the emperor Aurelianus abandoned the province at the beginning of the 270's and withdrew the army to the Danube defence line.

In the line of the limes in today's Mureş (Maros) County, we know of three auxiliary forts, along with their adjoining settlements which are loca- ted in today's Brâncoveneşti (Marosvécs), Călugăreni (Mikháza) and Sărăţeni (Sóvárad).

The Călugăreni auxiliary fort played an important strategic role in the defence of the Niraj (Nyárád) valley. During the $2^{\text {nd }}$ and $3^{\text {rd }}$ century, the more than forty hectares site was the most important economic and military centre in the region. Based on archaeological prospections and geophysical surveys, the ground plan and the layout of the 2.3-hectare large rectangular fort (castrum / castellum) strictly followed the rules of Roman military architecture.

The fort was oriented NE-SW and is located in the central part of the archaeological site. [3, 4] The settlement (vicus militaris) developed around it and is located in the western part of the present village and the arable land between Călugăreni and Dămieni (Deményháza). (Figure 1. and 2.)

The main aim of the current excavation is to investigate the headquarter building (principia) located at the crossroads of major roads of the fort and a residential area from the vicus. 


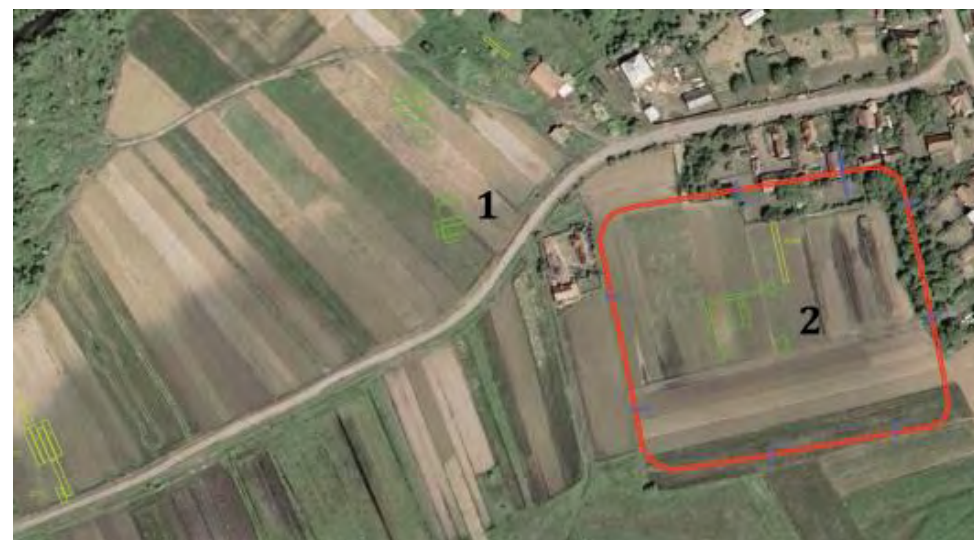

Figure 1. The excavation areas at the (1) vicus and the (2) auxiliary fort (made by Nándor Laczkó)

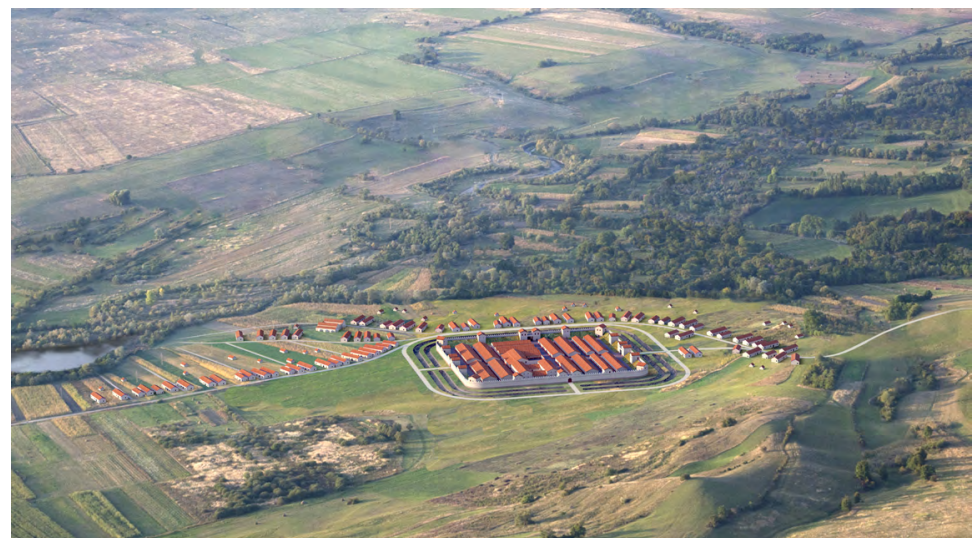

Figure 2. Virtual reconstruction of the site (made by Zsolt Vasáros)

\section{Experimental}

\subsection{Brief review of the samples}

The iron slag samples studied are presented in Table 1. Most of them were unearthed at the residential area discovered at the Călugăreni military settlement (vicus) during the excavations performed in 2013-2014, situated on the trench C, C1, C2 of the site. The finds discovered after 2015 belong to the trenches A2, A5, A2015 and A6 from the 3rd century phase of the headquarter building (principia). In the selection of the samples chosen for this study, besides the archaeological relevance, the assurance of the adequate probe quantity in order to complete the planned investigations was considered.

Macroscopic characterization of the samples was performed by visual examination, in daylight, under a magnifying glass of $5 \mathrm{x}$ magnifying power. The macrophotos were obtained using a
LUMIX TS7 digital camera of 20.4 Megapixels, at the same time and in the same conditions, and are presented in Figure 3. and 4.

Due to the relatively small number of specimens selected, the classification of the probes associated with the excavation trench and the context and macroscopic characteristics was not possible. The samples collected on the vicus territory typically are partially glassy, with dark grey and/or black zones on the outer surfaces, containing various quantity of differently sized gas inclusions (lunkers, vesicles) and iron inclusions (metallic droplets).

The macroscopic morphology of the samples 2008, 2155, 2355, 2356, 4009 and 4264 is pumiceous (spongy) and pronouncedly vesicular (with many gas lunkers) assuring their low density. They are very heterogeneous, with greyish, reddish, blackish, clayish-yellow with more or less crystallized or glassy zones on the surface. In 
Table 1. The iron slag samples

\begin{tabular}{|c|c|c|c|c|}
\hline No. & $\begin{array}{c}\text { Small } \\
\text { find } \\
\text { no. }\end{array}$ & Trench & Context & $\begin{array}{c}\text { Excav. } \\
\text { year }\end{array}$ \\
\hline \multicolumn{5}{|c|}{ Finds from the vicus } \\
\hline 1 & 2008 & C & 2000 & 2013 \\
\hline 2 & 2155 & C & 2001 & 2013 \\
\hline 3 & 2318 & C & 2005 & 2013 \\
\hline 4 & 2342 & C & 2005 & 2013 \\
\hline 5 & 2355 & C & 2009 & 2013 \\
\hline 6 & 2356 & C & 2009 & 2013 \\
\hline 7 & 4009 & C2 & 2039 & 2014 \\
\hline 8 & 4137 & C1 & 2034 & 2014 \\
\hline 9 & 4169 & C2 & 2039 & 2014 \\
\hline 10 & 4222 & C1 & 2038 & 2014 \\
\hline 11 & 4251 & C1 & 2035 & 2014 \\
\hline 12 & 4264 & C1 & 2038 & 2014 \\
\hline Finds from the principia & & \\
\hline 13 & 10218 & A2 & 109 & 2015 \\
\hline 14 & 10532 & A5 & 250 & 2016 \\
\hline 15 & 10661 & A5 & 339 & 2016 \\
\hline 16 & 10673 & A2016 & 346 & 2016 \\
\hline 17 & 11145 & A6 & 443 & 2017 \\
\hline
\end{tabular}

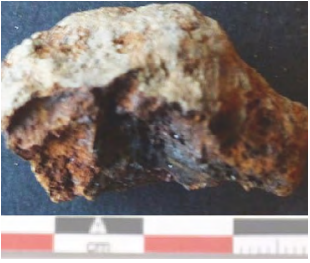

2008

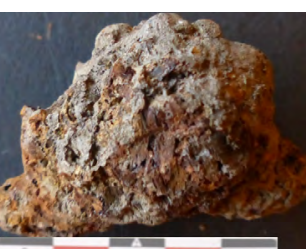

2355

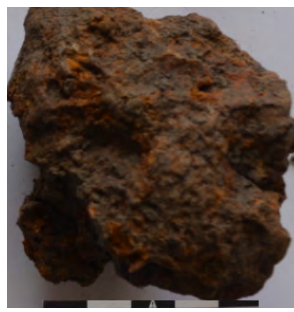

4169

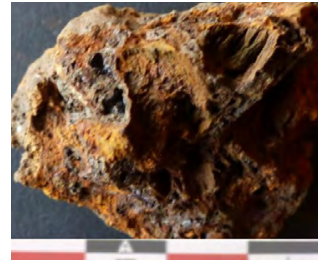

2155

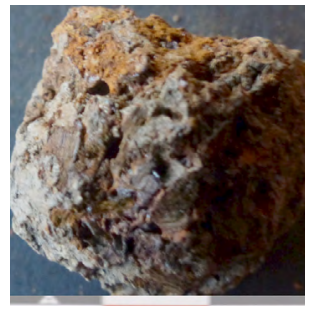

2356

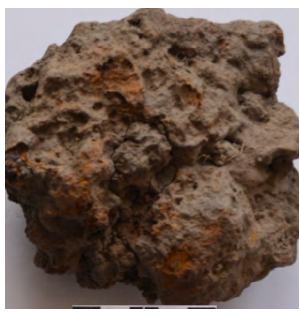

4222

most samples variously sized black magnetite crystals are embedded, and every sample contains - in various quantities - differently sized iron droplets. The inside of the vesicles is usually a blackish, frequently glassy "nest" with metal globules.

The surface of samples 2318, 2340, 4169, 4222 and 4251 is also heterogeneous, but (excepting 2318 with a clayish core) are dark grey or blackish inside. The structure is denser, assuring a greater hardness, so pulverisation is usually difficult. Sample 4137 is sandwich-structured: a 3-4 mm thick terracotta outer layer which covers a 3-4 mm thick black inner layer, which in turn covers a terracotta core.

Macroscopic morphology of the samples unearthed at the principia show some differences when compared to the vicus samples. The relatively dense, stratified 10218 contains plenty of small vesicles. The outer clayish layer is pulverulent, the vitrified core being blackish, with many small metallic globules; so its fracturation and trituration is difficult.The dark grey sample 10532 is compact, with large glassy vesicles nesting

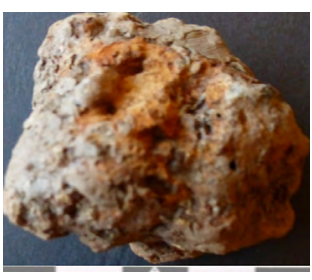

2318

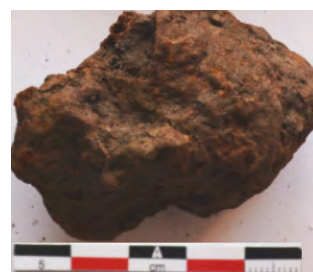

4009

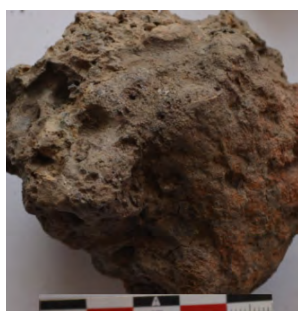

4251

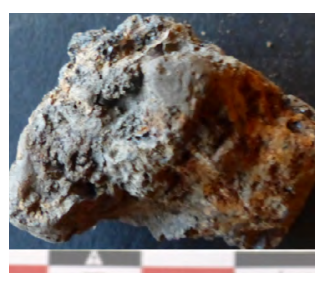

2342

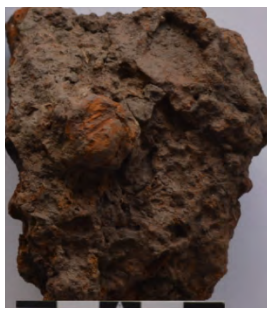

4137

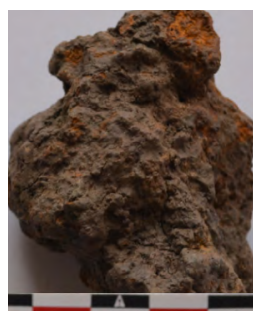

4264

Figure 3. Macrophotos of the samples finds from the vicus 


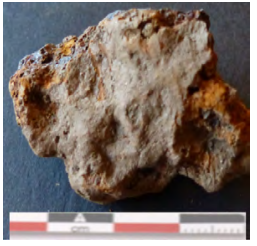

10218

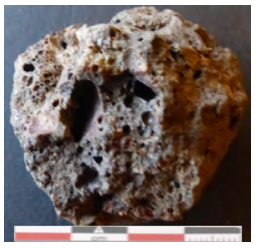

10532

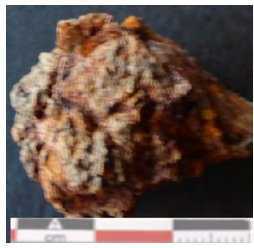

10661

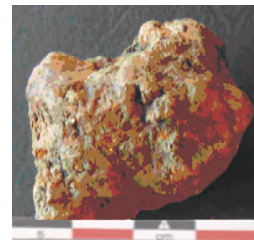

10673

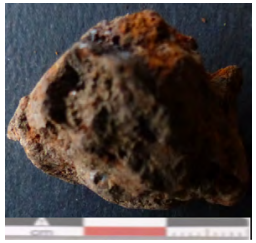

11145

Figure 4. Macrophotos of the samples finds from the principia

many iron "beads". It is brittle, but its grinding is difficult. The compact 10661 is even harder, but is fissile (easily splits into layers). The surface is grey, the inside is clayish red and with some small iron globules in the blackish cracks. The lighter, spongy, moderately blistered 10673 and 11145 are susceptible to lamellary-columnal fracturation and can be easily ground. Their surface is greyish-red, their core is reddish-clay, lamellary structured, with some white crystalline material, larger magnetite crystals and iron inclusions.

\subsection{Investigation methods and results}

\subsubsection{Optical microscopy (OM)}

The microphotos [5, 6] were obtained at 500x magnification on the raw outer surface, and the fresh, rough (unpolished) core surface (cleavage) obtained by crushing the samples, were registered using a Dino-Lite Edge AM4115T digital microscope without polarisation and the DinoCapture 2.0 image processing software. Some of the most characteristic microphotos are presented on the Figures 5. és 6.

The mineralogical interpretation of the OM data obtained (the identification of the mineral components) is in progress, however, some general characteristics of the samples can be concluded.

The totality of the samples contain, in different quantities, differently sized gas lunkers and iron inclusions (metallic droplets separated typically in the inside of the gas holes or in the cracks where they were formed). Additionally, cubic magnetite crystal inclusions appear in every sample, although they are fewer. [7]

\subsubsection{FTIR spectroscopy}

FTIR spectra of the archaeological finds can be used as a convenient tool for the elucidation of the chemical processes that occured during their genesis (fabrication or simply formation as in the case of the iron slags), and the geochemical (alteration) processes taking place during their burial [8-10]. In the case of the archaeological iron slags, the wide, tipycally medium intensity absorption bands appearing in the $3700-3000 \mathrm{~cm}^{-1}$ spectral region, generated by free and (physically or chemically) bonded $\mathrm{OH}$, together with the
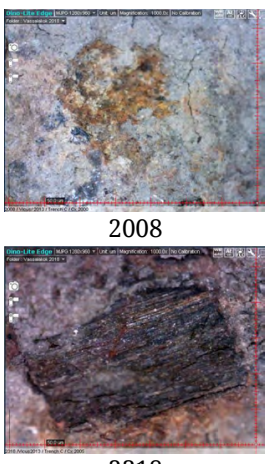

2318

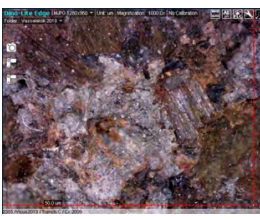

2355

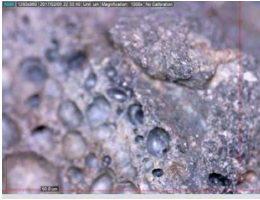

4009

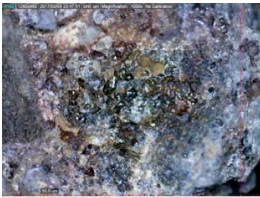

4169

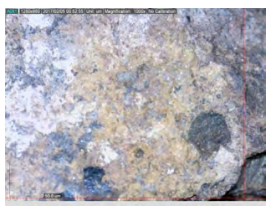

4251

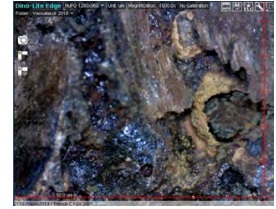

2155

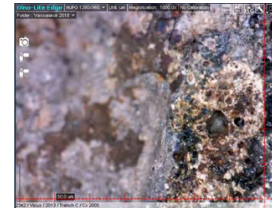

2342

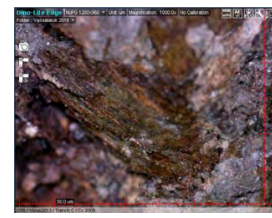

2356

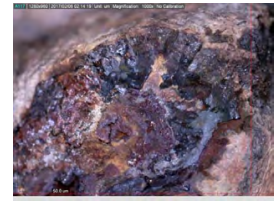

4137

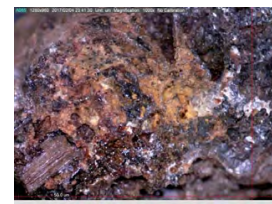

4222

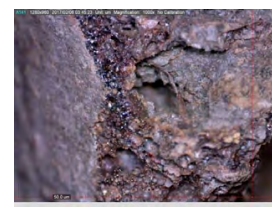

4264
Figure 5. Selected microphotos of the vicus samples (500x) 


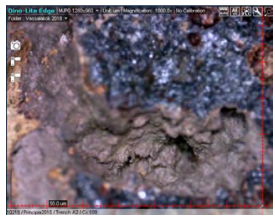

10218

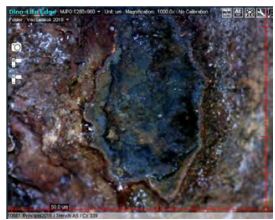

10661

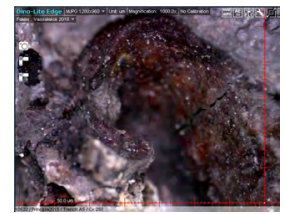

10532

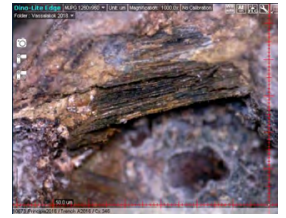

10673
Figure 6. Microphotos obtained on principia samples (500x)

wide, intense, quasi-symmetrical (alumino)silicate bands shown between $1100-1000 \mathrm{~cm}^{-1}$, reliably characterize the structural order (or disorder) of the samples. Structural ordering of the iron slags is the result of the crystallization that occurred during the cooling of the melted material, followed by the metamorphosis (alteration) processes occurring during burial, the latter largely depending on the local environmental particularities of the archaeological site. The spectral components identified by means of the spectral deconvolution of the above mentioned main absorpion bands can confirm (reinforce) the mineralogical componency resulting from the petrographic microscopy, $\mathrm{XRD}$ and macroelemental analysis data of the samples.

The FTIR absorption spectra in the $4000-400 \mathrm{~cm}^{-1}$ region were obtained on $\mathrm{KBr}$ pellets of the agate mortar pulverised samples without any kind of prior thermal treatment. The spectra were re-

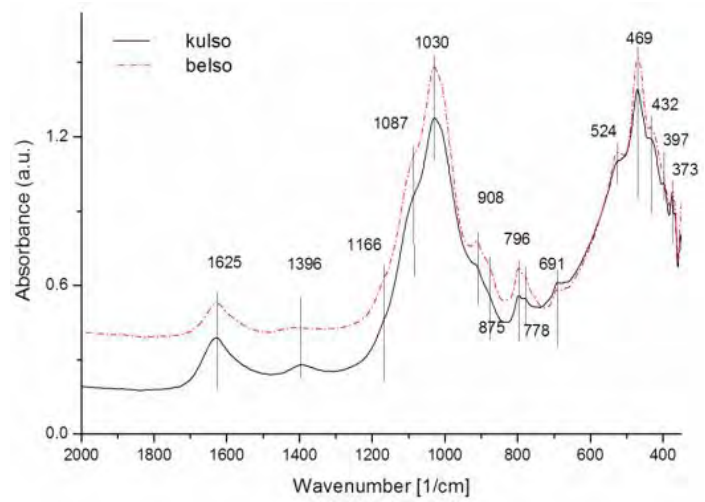

Figure 7. FTIR spectrum of the iron slag surface layer (black) vs. the inside material (red); sample 4009

corded using a JASCO FTIR 6100 spectrometer of $1 \mathrm{~cm}^{-1}$ resolution. The composition of the pulverised samples was, as far as possible, close to the homogenized bulk composition. FTIR spectra on the surface layer and the inside of the 4009 sample in the 2000-400. $\mathrm{cm}^{-1}$ region were also recorded (Figure 7.)

Due to the absence of deconvolution data in relation to the major $\mathrm{OH}$ absorption band, an adequate interpretation of the $4000-2000 \mathrm{~cm}^{-1}$ spectral region is uncertain, assignation of the main absorption peaks was made in the 2000$400 \mathrm{~cm}^{-1}$ region (Table 2. presents the data obtained for the vicus samples 4009-4264).

As an exception, in case of three selected samples that presented a peculiar archaeological interest (the 2155, from the vicus, and the 10218 and 10532, from the principia), the peak assignation was extended to the whole spectrum (Figure 8., Table 3.).

Table 2. Assignments of the FTIR absorption peaks (bulk) in the $2000-400 \mathrm{~cm}^{-1}$ region

\begin{tabular}{|c|c|c|c|c|c|c|}
\hline \multicolumn{6}{|c|}{ Wavenumbers $\left(\mathrm{cm}^{-1}\right)$} & \multirow{2}{*}{ Assignments* } \\
\hline 4009 & 4137 & 4169 & 4222 & 4251 & 4264 & \\
\hline 1630 & 1620 & 1625 & 1620 & 1627 & 1630 & $\mathrm{OH}, \mathrm{FeO}(\mathrm{OH})$ \\
\hline $1394 \mathrm{sh}$ & 1698 & 1396 & 1396 & 1394 & 1401 & $\mathrm{CO}_{2}$ \\
\hline $\begin{array}{l}1167 \mathrm{sh} \\
1076 \mathrm{sh} \\
1045\end{array}$ & $\begin{array}{l}1084 \mathrm{sh} \\
1029\end{array}$ & $\begin{array}{l}1166 \mathrm{sh} \\
1087 \mathrm{sh} \\
1030\end{array}$ & $\begin{array}{l}1166 \mathrm{sh} \\
1087 \mathrm{sh} \\
1030\end{array}$ & $\begin{array}{l}1094 \mathrm{sh} \\
1025\end{array}$ & $\begin{array}{l}1165 \mathrm{sh} \\
1080 \mathrm{sh} \\
1023\end{array}$ & $\begin{array}{l}\mathrm{SiO}_{4}, \mathrm{AlO}_{4} \\
\text { dominant mode } \\
\mathrm{FeO}(\mathrm{OH}) 1084\end{array}$ \\
\hline $\begin{array}{l}913 \\
876\end{array}$ & 882 & $\begin{array}{l}908 \\
875\end{array}$ & $\begin{array}{l}908 \\
875\end{array}$ & $906 \mathrm{sh}$ & $913 \mathrm{sh}$ & $\begin{array}{l}\mathrm{Fe}_{2} \mathrm{O}_{3} 1100 \\
\mathrm{CO}_{2} 880-860\end{array}$ \\
\hline $\begin{array}{l}794 \\
776\end{array}$ & $\begin{array}{l}796 \\
779\end{array}$ & $\begin{array}{l}796 \\
778\end{array}$ & $\begin{array}{l}796 \\
778\end{array}$ & 798 & $\begin{array}{l}796 \\
778\end{array}$ & $\begin{array}{l}\mathrm{SiO}_{4}, \mathrm{AlO}_{4} \\
\text { dominant mode } \\
\mathrm{FeO}(\mathrm{OH}) 803\end{array}$ \\
\hline $\begin{array}{l}524 \\
462 \\
421\end{array}$ & $\begin{array}{l}526 \\
467 \\
435\end{array}$ & $\begin{array}{l}524 \\
469 \\
462 \mathrm{sh}\end{array}$ & $\begin{array}{l}524 \\
469 \\
462 \mathrm{sh}\end{array}$ & $\begin{array}{l}524 \mathrm{sh} \\
467 \\
428\end{array}$ & $\begin{array}{l}526 \mathrm{sh} \\
471 \\
421\end{array}$ & $\begin{array}{l}\mathrm{Fe}_{2} \mathrm{O}_{3} 550,417 \\
\mathrm{FeO}(\mathrm{OH}) 470,410 \\
\mathrm{Si}-\mathrm{O}, \mathrm{Al}-\mathrm{O}, 470-460\end{array}$ \\
\hline
\end{tabular}

* Based on the RRUFF database 
a.

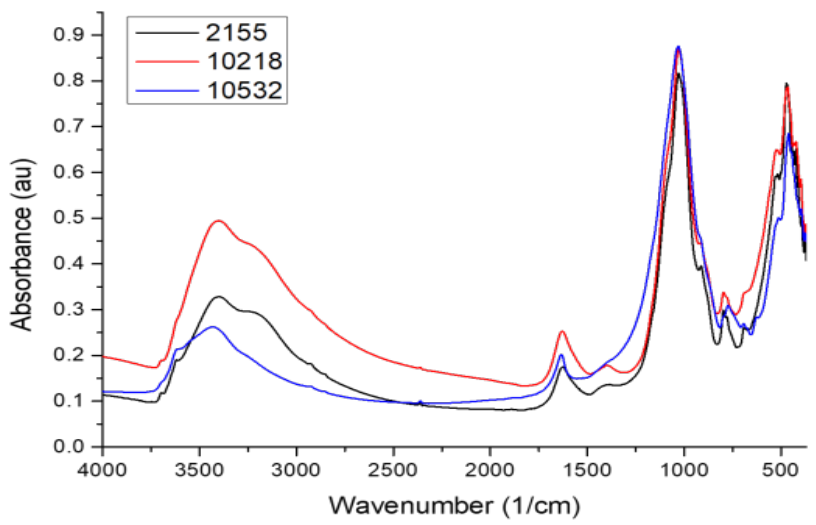

b.

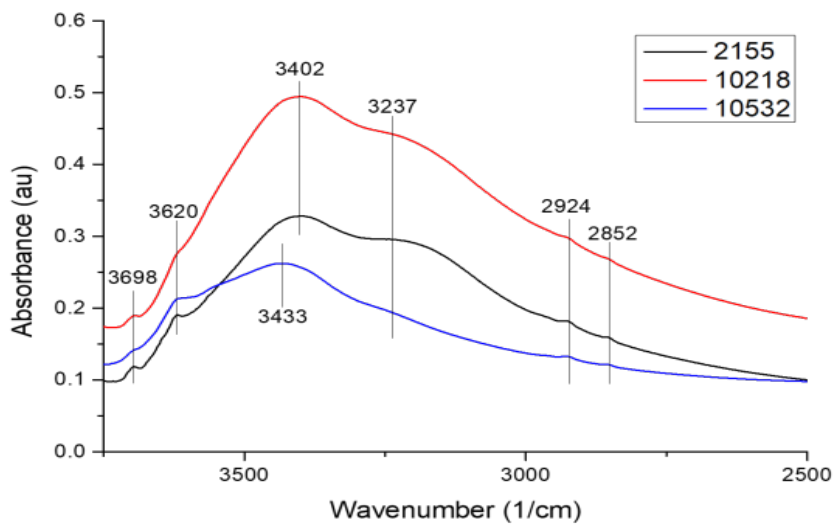

c.

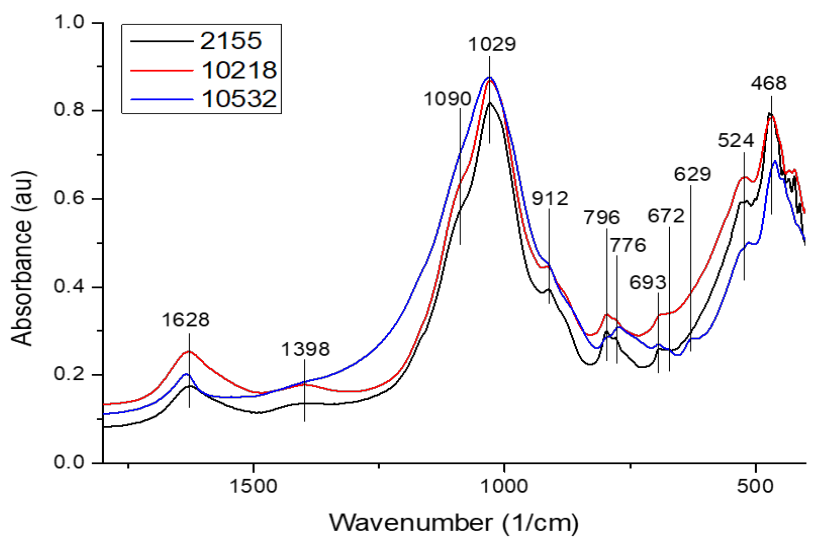

Figure 8. FTIR spectra of three iron slags selected for detailed characterization: (a) 4000-400 $\mathrm{cm}^{-1}$, (b) $4000-2500 \mathrm{~cm}^{-1}$, (c) $2000-400 \mathrm{~cm}^{-1}$ 
Table 3. FTIR data of the three selected samples in the 4000-400 $\mathrm{cm}^{-1}$ region

\begin{tabular}{|c|c|c|c|}
\hline \multicolumn{3}{|c|}{ Wavenumbers $\left(\mathrm{cm}^{-1}\right)$} & \multirow{2}{*}{ Assignments* } \\
\hline 2155 & 10218 & 10532 & \\
\hline \multirow[t]{2}{*}{3618} & 3621 & 3616 & \multirow{7}{*}{$\mathrm{OH}$} \\
\hline & & 3549 & \\
\hline 3401 & 3403 & & \\
\hline 3221 & 3220 & 3243 & \\
\hline 2923 & 2924 & 2914 & \\
\hline 2853 & 2851 & 2854 & \\
\hline 1627 & 1629 & 1635 & \\
\hline 1398 & 1398 & 1393 & $\mathrm{SiO}_{4}$ \\
\hline 1090 & 1090 & & \multirow{3}{*}{$\begin{array}{l}\mathrm{SiO}_{4}, \mathrm{AlO}_{4} 1100-900 \\
\mathrm{FeO}(\mathrm{OH}), \mathrm{Fe}_{2} \mathrm{O}_{3} 1105,1084\end{array}$} \\
\hline 1029 & 1030 & 1030 & \\
\hline 912 & 915 & 914 & \\
\hline 797 & 797 & 799 & $\mathrm{SiO}_{4}$ 798-782, $\mathrm{FeO}(\mathrm{OH}) 803$ \\
\hline 779 & 777 & 773 & $\mathrm{FeO}(\mathrm{OH})$ \\
\hline \multirow[t]{2}{*}{693} & 695 & 693 & $\mathrm{AlO}_{4}$ \\
\hline & & 627 & $\mathrm{SiO}_{4} 630$ \\
\hline 520 & 523 & 515 & $\mathrm{Fe}_{2} \mathrm{O}_{3}$ \\
\hline 471 & 465 & 431 & $\begin{array}{l}\mathrm{FeO}(\mathrm{OH}) 470 \\
\mathrm{Fe}_{2} \mathrm{O}_{3} 432\end{array}$ \\
\hline
\end{tabular}

According to Figure 7., in the case of sample 4009, the FTIR spectra corresponding to the outer layer and the inside of the sample in the 2000-400 $\mathrm{cm}^{-1}$ region practically coincide. This indicates that even if some geochemical processes took place during burial, their influence, at least in this case, is negligible. Corroborating this with the Table 2. data (which indicate a parallelism of the spectral behaviour of the different samples), it is probable that in most cases the FTIR study carried out on probes corresponding to the bulky composition of the samples is good enough.

Comparing the absorption peak assignments presented in the Table 2. and 3. indicates that the FTIR spectroscopic behaviour of the two sample groups (from the vicus and the principia), at least in the region $2000-400 \mathrm{~cm}^{-1}$, is also similar, even if some minor differences can be observed. So far, in case of the Călugăreni site, the FTIR spectroscopic behaviour of the slag samples does not depend on the exact location where they were unearthed. However, this conclusion (or further conclusions) needs more data obtained by further methods, such as the actual ongoing XRD, XRF, ICPMS investigations.

\section{Conclusions}

The Roman auxiliary fort located at Călugăreni, on the Eastern sector of the Dacian limes, established after the Roman conquest of the Dacian kingdom, was a strategically important military centre. During the still ongoing archaeological excavations a large quantity of iron slag remains have been unearthed. However, to date, no trace of bloomery or smithery workshops was found at the location. In consequence, the source of the slag finds is unknown; they could originate equally from the local processing of some imported iron blooms, or from the recovery of damaged iron objects (weapons and household tools) by reparation or recycling. The issue could be clarified to some extent by means of the archaeometric study of the slag finds. In this case, the thorough investigation of 17 carefully selected iron slag samples was initiated. In this first stage, after a macroscopic evaluation of the morphology, optical microscopy and FTIR spectroscopy was carried out on the specimens.

According to the characteristic FTIR absorption peaks appearing in the spectral domain 2000$400 \mathrm{~cm}^{-1}$, the investigated samples among some carbonates (and possibly aluminates) are constituted from silicates. The carbonates could have been formed in carbonation processes taking place during burial, as a consequence of the environmental conditions.

According to the microphotos registered, the main crystal phase of the samples identified in the absence of polarized light is fayalite $\left(\mathrm{Fe}_{2} \mathrm{SiO}_{4}\right)$; dendritic wüstite and cubic magnetite are also observed in practically every sample. The samples generally are characterized by a vast amount of metallic iron inclusions, and the presence of some glassy phases. These considerations indicate that the (smelting or smithy) processes the samples were subjected to took place at relatively high temperatures, probably in a reducing atmosphere or environment.

According to the macroscopic characteristics, the possibility that the slags could be smelting by-products can't be excluded. The morphology of some samples are close to that of the tap slags: these specimens are more dense, with small blow holes inside, as the tap slag froze outside the smelter. The lower density, sponge-like structured samples full of gas lunkers seem to have been cooled down inside the smelter (cinder).

In future, research will continue with petrographic microscopic and XRD investigation, and 
macro- and microelemental analysis of the samples. Naturally, we have to keep in mind that (as indicated by the standard deviation values associated with the previous PXRF elemental analyses of the surface composition of similar samples) these types of sample are very heterogeneous. [11, 12]. In consequence, conclusions referring to the slag's mineralogical and/or chemical composition have to be drawn very cautiously.

\section{Acknowledgement}

The archaeometric (archaeometallurgical) research carried out is part of the Project for Technical and Cultural Heritage Preservation in Transylvania, initiated and supervised by the Research Institute of the Transylvanian Museum Society. The financial support was assured by the $3272 / 4 / 2017 /$ HTMT grant of the Homeland Research Programme supervised by the Hungarian Science Abroad Presidential Committee of the Hungarian Scientific Academy.

The field research between 2013-2015 was organized as the archaeological field school of the international interdisciplinary project The Roman Limes as a European Cultural Landscape coordinated by: the Mureş County Museum and the Winckelman Institute of the Humboldt University of Berlin. The field school involved the participation and cooperation of students and lecturers of archaeology, geophysics, architecture, conservation and restoration from the University of Cologne, the University of Pécs, the Budapest University of Technology and Economics, the Eötvös Loránd University, the University of Applied Sciences Erfurt, the Babeş-Bolyai University of Cluj-Napoca, and the Petru Maior University of Târgu Mureş.

Since 2016, the archaeological research was supported by the Mureş County Council, the Chair of the Roman Provinces at the Archaeological Institute of the University of Cologne, the Erasmus Fund of the Humboldt University of Berlin, and the Romanian Ministry of Culture.

\section{References}

[1] Matei-Popescu F., Tुentea O.: The Eastern Frontier of Dacia. A Gazetteer of the Forts and Units. In: Orbis Romanus and Barbaricum. The Barbarians around the Province of Dacia and Their Relations with the Roman Empire. (Ed.: Bârcă V.). Mega Publishing House, Cluj-Napoca, 2016. 7-24.

[2] Höpken C. et al.: Wachtürme am Dakischen Ostlimes zwischen Brâncoveneşti und Călugăreni (jud. Mureş/RO). Archäologisches Korrespondenzblatt 46. (2016) 241-254.

[3] Pánczél Sz. P.: The Roman Fort from Călugăreni (Mureş County, Romania). In: LIMES XXII. Procee- dings of the 22nd International Congress of Roman Frontier Studies Ruse, Bulgaria, September 2012. (Eds.: Vagalinski L., Sharankov N.). National Archaeological Institute with Museum, Sofia, 2015. 909-916.

[4] Pánczél Sz. P. et al.: A mikházi római segédcsapattábor kutatása/The research at the Roman auxiliary fort of Mikháza/Călugăreni. Magyar Régészet/ Hungarian Archaeology, 2018 spring, 13-20.

http://files.archaeolingua.hu/2018TA/Pa\%b4ncze\%b4l_E18TA.pdf

[5] Buchwald V. F., Wivel H.: Slag analysis as a method for the characterization and provenancing of ancient iron objects. Materials Characterization, 40. (1998) 73-96.

https://doi.org/10.1016/S1044-5803(97)00105-8

[6] Kramar S. et al.: Mineralogical and geochemical characterization of Roman slag from the archaeological site near Mosnje (Slovenia). Materials and technology, 49. (2015) 343-348.

http://mit.imt.si/Revija/izvodi/mit153/kramar.pdf

[7] Mihailova I., Mehandjiev D.: Characterization of fayalite from copper slags. Journal of the University of Chemical Technology and Metallurgy 45. (2010) 317-326.

http://dl.uctm.edu/journal/node/j2010-3/12_Irena_Mihailova_317-326.pdf

[8] Sowmya T., Sankaranarayanan S. R.: Spectroscopic analysis of slags - preliminary observations. In: VII. International Conference on Molten Slags, Fluxes and Salts, The South African Institute of Mining and Metallurgy, South Africa, 2004. 693-697.

http://www.saimm.co.za/Conferences/MoltenSlags2004/693-Sowmya.pdf

[9] Olovčić A., Memić M, Žero S, Huremović J., Kahrović E.: Chemical Analysis of Iron Slags and Metallic Artefacts from Early Iron Age. International Research Journal of Pure and Applied Chemistry, 4. (2014) 859-870.

https://doi.org/10.9734/IRJPAC/2014/12248

[10] Sheikh M. R. et al.: Characterization of iron slag of Kakching, Manipur by X-ray and optical spectroscopy. Indian Journal of Pure \& Applied Physic, 48. (2010) 632-634.

http://nopr.niscair.res.in/bitstream/123456789/ 10153/1/IJPAP\%2048\%289\%29\%20632-634.pdf

[11] Chuenpee T., Won-In K., Natapintu S. Takashima I.: Archaeometallurgical Studies of Ancient Iron Smelting Slags from Ban Khao Din Tai Archaeological Site, Northeastern Thailand. Journal of Applied Sciences, 14. (2014) 938-943.

https://doi.org/10.3923/jas.2014.938.943

[12] Scott R. B. Eekelers K., Degryse P.: Quantitative chemical analysis of archaeological slag material using handheld X-ray fluorescence spectrometry. Applied spectroscopy, 70. (2016) 94-109. https://doi.org/10.1177/0003702815616741 